\title{
Reproductive Biology and Phenology of Croton scabiosus Bedd. - An Endemic Tree Species of Southern Eastern Ghats of Kadapa District, Andhra Pradesh
}

\author{
L. Nagireddy ${ }^{1}$,S. Nazaneen Parveen ${ }^{1^{*}}$, T. Pullaiah ${ }^{2 * *}$ \\ ${ }^{1}$ Department of Environmental Science, Yogi Vemana University, Kadapa-516004, Andhra Pradesh, India \\ ${ }^{2}$ Department of Botany, Sri Krishnadevaraya University, Anantapur- 515003 Andhra Pradesh, India
}

\begin{abstract}
Croton scabiosus Bedd. is an endemic tree species of Southern Eastern Ghats of Kadapa District, Andhra Pradesh. In the present study observations were made on reproductive biology and phenology of Croton scabiosus at Idupulapaya reserve forest, Vempalli, Kadapa. The observations on phenological events i.e. leaf initiation, flowering, fruiting and leaf fall were recorded between December 2013 and November 2014. Observations revealed a pattern of two episodes of flowering in the months of January to June and September to October. The peak flowering was observed in the month of March and flower anthesis occurs during morning to evening $(0600 \mathrm{~h}$ to $1800 \mathrm{~h})$. Inflorescence is terminal simple raceme. Male flowers are on the upper portion and female on the lower portion of the inflorescence. Flowers are minute, monochlamydeous and actinomorphic. Floral morphology, breeding systems - geitonogamy and xenogamy, stigma receptivity, pollen output per anther/flower, pollen ovule ratio and fruit set percentage were recorded.
\end{abstract}

Keywords: Croton scabiosus , endemic tree, reproductive biology, phenology.

\section{Introduction}

Croton scabiosus Bedd. (Euphorbiaceae) is a small tree of about $6 \mathrm{~m}$ high, endemic to Southern Eastern Ghats of Andhra Pradesh (Ahmedullah and Nayar, 1986; Babu, 1997). The Species is represented by small populations with scattered distribution in dry deciduous forests of Southern Andhra Pradesh (Balakrishnan and Chakrabarty, 2007). It is found in Anantapuram, Kadapa and Nellore Districts of Andhra Pradesh, India. It is assessed as vulnerable according to IUCN Red list status (Salamma and Rao, 2014). This plant is locally known as Puruguchekka, Verrichilla or Yerrichilla. It is medicinally important as the seeds of this species are used as antidote for snake bite and scorpion sting in the local markets (Devi et al., 2011). It has a very attractive silvery to golden foliage and can be recommended as an ornamental garden plant (Neginhal, 2004). Population of this species is declining in the native habitat. As this is an endemic and economically important tree species, and populations are small, the conservation of this species is an important aspect. For the same thorough knowledge of reproductive biology, breeding systems and phenology is required. Hence the present study.

\section{Materials and Methods}

The present study was undertaken in the dry deciduous forest of Idupulapaya. Total of 25 individual trees were selected in the natural populations in Idupulapaya reserve forest, Vempalli, Kadapa district. The study site lies N$14^{0} 19.418$ Latitude, E- $78^{0} 31.468$ Longitudes and the elevation of $275 \mathrm{~m}$, above the sea level. Phenological observations were made for the permanently marked trees. Observations on flowering initiation, duration of flowering season, anthesis, anther dehiscence, stigma receptivity, breeding systems, fruit set, and seed dispersal were studied as described by Shivanna and Rangaswamy (1992).The number of inflorescences per tree and number of male and female flowers per inflorescence were counted. From each tree ten inflorescences were maintained for counting the opened flowers. The other observations include the structure of male flowers, number of stamens, anther dehiscence, number of pollen in each anther and structure of female flowers and gynoecium, number of carpels and number of ovules per carpel.

Flowering phenology was recorded based on flowering initiation, anthesis and anther dehiscence during the flowering season of January to June. The anthesis was recorded on daily basis on the mature floral buds of 10 inflorescences each from ten marked trees. Fifteen mature buds were observed for recording the time taken to reach various developmental stages from anthesis to anther dehiscence in successive days. Breeding behavior (geitonogamy and xenogamy) was tested by controlled pollination in bagged flowers. Pollination experiments were performed by dusting pollen obtained from freshly dehisced anthers on the receptive stigmas of the female flower of same tree (geitonogamy) to test for self compatibility and also on the female flower of different trees (xenogamy) to test for out crossing ability. The pollinated flowers were bagged and observed periodically for fruit formation (Shivanna and Rangaswamy 1992).

\subsection{Pollen size}

Pollen size and pollen tube length was measured with an ocular micrometer under light microscope following the procedure of Mekone and Webb (1988). 


\subsection{Pollen viability and germination}

Pollen viability was assessed by 2, 3, 5 - Triphenyl tetrazolium chloride (TTC) test. To study the pollen germination in vitro, pollen grains were incubated in Brewbakers medium with different concentrations (5, 10 and $15 \%$ ) of sucrose (Brewbaker and Kwack, 1963). After 4 hours the percentage of pollen germination and tube elongation was noted.

\subsection{Pollen output/ anther/flower}

Pollen production was recorded on 10 individual trees during flowering and the pollen count was made by selecting anthers. In each tree, five mature buds were selected and in total 10 trees were observed for pollen output per anther and flower following the method of Kearns and Inouye (1993).

\subsection{Pollen ovule ratio}

The number of ovules per flower was observed by taking the cross section of ovary to determine pollen ovule ratio. Pollen ovule ratio was calculated following the method of Cruden (1977).

\subsection{Stigma receptivity}

During anthesis 10 flowers each from 5 inflorescences were selected to test stigma receptivity. Experiments were conducted with Hydrogen Peroxide; a drop was added to stigma of flower during anthesis. Observations were recorded if stigma showed pure effervescence producing bubbles resulting from catalase enzyme activity (peroxidase) method (Dafni, 1992). The time of stigma receptivity was checked on $1^{\text {st }}$ day, 2 nd day and $3^{\text {rd }}$ day of anthesis of flowers.

\section{Results}

\subsection{Phenology}

In Croton scabiosus leaves appear orange-red colour in November. Leaf fall occurs in November-December and leaf flush in January to March (Fig-1 A-C). Flowering occurs in two episodes per year. In the first episode it starts from the first week of January and extends up to last week of June. The peak flowering was observed in the March month. It flowers again from September to October. The flower buds take 10 days from initiation to anthesis. The average life span of each flower is 2-4 days. It takes at least one hour for complete unfolding of floral parts. Day long anthesis was observed, i.e. anthesis occurs from morning to evening between $0600 \mathrm{~h}$ to 1800 , though it is low between $1000 \mathrm{~h}$ to 1600h. Anthers dehisce after flower anthesis. Flower bud initiation to termination of the flowering at inflorescence level takes 40 days time. The time taken from initiation to dehiscence of fruit is 28 days.

\subsection{Floral Biology}

Croton scabiosus is a monoecious tree with separate male and female flowers borne together on terminal simple racemes. Female flowers are borne on lower and male on upper portion of the inflorescence (Fig-1D). Each inflorescence is about $5.5 \mathrm{~cm}$ to $13.2 \mathrm{~cm}$ length and bears 5 12 female flowers and 20-52 male flowers. Female and male flowers ratio is approximately 1:4. The male flowers are small dichlamydeous, actinomorphic and pentamerous. The size of the flower is $0.6-0.7 \mathrm{~mm} \times 0.5-0.6 \mathrm{~mm}$. The sepals are five in number, polysepalous, valvate and pale green in colour. The corolla contain five petals, polypetalous, valvate and pale green in colour. Stamens are 12 -20 in each flower, cream coloured and $1 \mathrm{~mm}$ in size. Anthers are dithecous and dehisce by longitudinal slits (Table -1). Anther dehiscence occurs after flower anthesis. Pollen grains are light yellow in colour, wet and monads. Pollen size is $44.82 \pm 4.06 \mu \mathrm{m}$. Pollen output per anther is $219.4 \pm 24.76$ and per flower is 2637.18 \pm 53.23 . Female flowers minute, pedicillate, monochlamydeous, pentamerous, actinomarphic and hypogynous. It is oval shaped, light green in colour. The size of the flower is $6.8 \pm 0.6 \mathrm{~mm} \times 5.4 \pm 0.4 \mathrm{~mm}$.Perianth lobes are five, light green, free and valvate. Gynoecium light green in colour, tricarpellary, syncarpous, ovary superior and trilocular. Each locule contains a single ovule on axile placentation. Styles are three, stigmas are forked, wet and shiny. Flower opening is acropetal at inflorescence level. Fruits are schizocarpic capsules, globose to sub globose and 3- valved (Fig. 1 F). Each fruit contain 3 seeds, very rarely four seeds occur (Table 1,4). Seeds are small and black with caruncle.

\subsection{Pollen output/ anther/flower}

Pollen output per anther is $219.4 \pm 24.76$ and pollen output per flower $2,637.18 \pm 53.23$

\subsection{Pollen viability and In vitro pollen germination}

In Croton scabiosus the pollen grains are round, monads and wet. The size is $44.82 \pm 4.06 \mu \mathrm{m}$. On the first day of anthesis the viability percentage is 48.25 and they were viable for 14 hours and on the second day pollen grains are not viable (Fig.2B). Effect of sucrose on in vitro pollen germination studies revealed that $38.7 \%$ pollen germinated with tube length of $373.2 \pm 6.45 \mu \mathrm{m}$ in $5 \%$ sucrose, $44.97 \%$ pollen germinated with tube length of $428.8 \pm 5.15 \mu \mathrm{m}$ in $10 \%$ sucrose and germination is $36.52 \%$ and tube length is $286.6 \pm 4.74 \mu \mathrm{m}$ in $20 \%$ sucrose i.e. the maximum number of pollen germinated is $10 \%$ sucrose (Table -2, Fig 2-A, B).

\subsection{Stigma receptivity}

The stigma receptivity was checked on first, second and third day of anthesis of flowers. Stigma receptivity occurs only on second day anthesis of flower. Stigma was not receptive on first and third day of anthesis of flower. 


\section{International Journal of Science and Research (IJSR) \\ ISSN (Online): 2319-7064}
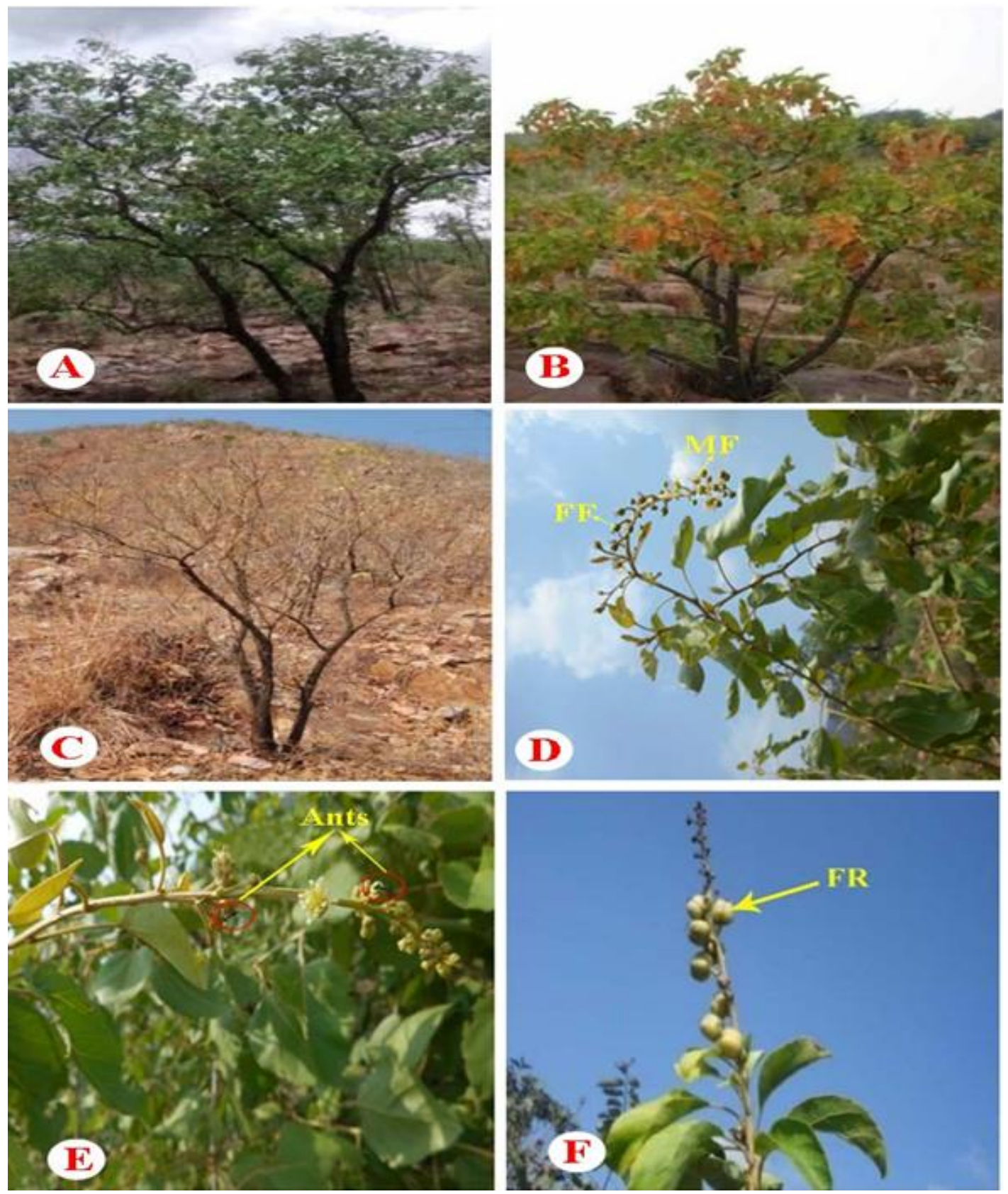

Figure 1A: Croton scabiosus Habit B: Tree with orange - red coloured leaves C: Tree with total leaf fall D: Inflorescence showing male and female flowers E: Inflorescence with ants F: Branch which fruits.(MF:Male flowers, FF:Female flower,FR:

Fruits

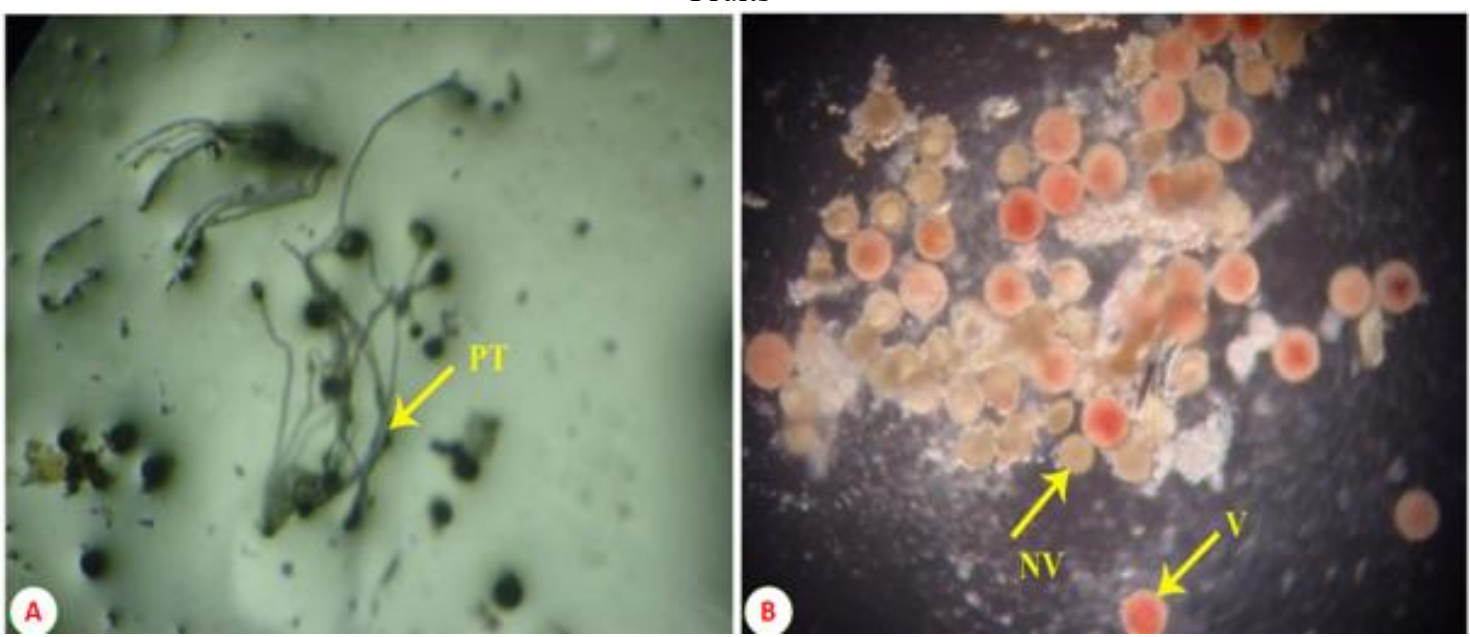

Figure 2A: In vitro pollon germination PT- pollen tube B.Pollen viabulity cheaked by TTC NV: Non viable pollen V.Viable pollen

Volume 5 Issue 1, January 2016 www.ijsr.net 


\section{International Journal of Science and Research (IJSR) \\ ISSN (Online): 2319-7064 \\ Index Copernicus Value (2013): 6.14 | Impact Factor (2014): 5.611}

\subsection{Pollination and Breeding behavior}

In Croton scabiosus the flowers are minute and unisexual, male and female flowers are borne on simple racemes inflorescence. Flowers have nectar in traces. The flowers were visited by good number of ants and thrips throughout the flowering season (Fig. 1E). They were found during the day carrying and transfer considerable amount the pollen grain to the female flower. The other insects like honey bees and butterflies are not observed on Croton scabiosus.
In natural conditions fruit set was $46 \%$. The percentage of fruit set through xenogamy was $17.65 \%$ and through geitonogamy was $23 \%$. The results show the species is selfcompatable. The time required from initiation fruit to dehiscence is 28 days. The seeds obtained by natural and artificial germinated up to $10 \%$ only.

Table 1: Floral biology in Croton scabiosus

\begin{tabular}{|c|c|}
\hline Male flower: & Observations \\
\hline Shape & Cup \\
\hline Flower colour & Creamy white colour \\
\hline Number of male flowers/Inflorescence & $20-52$ \\
\hline Male flower length & $0.6 \pm 0.7 \mathrm{~mm}$ \\
\hline Male flower width & $0.5 \pm 0.6 \mathrm{~mm}$ \\
\hline Calyx & 5 Sepals, free, valvate \\
\hline Corolla & 5 Petals, pale green in colour, free, valvate \\
\hline Stamens colour & Pale green \\
\hline Stamen size & $0.47 \pm 0.04 \mathrm{~mm}$ \\
\hline Anther colour & Creamy colour \\
\hline Anther size & $1 \mathrm{~mm}$ \\
\hline Filament colour & Creamy colour \\
\hline Filament size & $0.36 \pm 0.04 \mathrm{~mm}$ \\
\hline Pollen grain colour & Light yellow \\
\hline Pollen grain nature and shape & Wet pollen grains and monads \\
\hline Pollen size & $44.82 \pm 4.06 \mu \mathrm{m}$ \\
\hline Pollen output per anther & $219.4 \pm 24.76$ \\
\hline Pollen output per flower & $2,637.18 \pm 53.23$ \\
\hline Pollen ovule ratio & 265492.33 \\
\hline \multicolumn{2}{|l|}{ Female Flower: } \\
\hline Shape & Oval \\
\hline Flower colour & Light green in colour \\
\hline Number of female flowers / Inflorescence & $5-10$ \\
\hline Female flower length & $6.8 \pm 0.6 \mathrm{~mm}$ \\
\hline Female flower width & $5.4 \pm 0.4 \mathrm{~mm}$ \\
\hline Perianth & 5 lobes, light green, free, valvate \\
\hline Gynoecium & Tricarpellary \\
\hline Style and stigma colour & Light yellow \\
\hline Ovary position & Superior, trilocular, with single ovule in each locule on axile placentation. \\
\hline Ovary colour & Light green \\
\hline Styles and stigmas & Styles 3 , each stigma is bilobed \\
\hline Number of locules per flower & Three locular \\
\hline Number of ovules per flower & Three ovules \\
\hline Nectar & Nectar is produced in traces \\
\hline Pollination & Entomophilous - ants and thrips observed as pollinators. \\
\hline Fruit & Schizocarpic capsule, globose to subglobose,3-valved \\
\hline Fruit length & $8.1 \pm 0.4 \mathrm{~mm}$ \\
\hline Fruit width & $9.4 \pm 0.6 \mathrm{~mm}$ \\
\hline Seed & Small black with caruncle. \\
\hline
\end{tabular}

Table 2: Pollen germination and pollen tube growth

\begin{tabular}{|c|c|c|c|c|}
\hline $\begin{array}{l}\text { Media } \\
\text { (Sucrose) }\end{array}$ & $\begin{array}{l}\text { No of } \\
\text { pollen } \\
\text { grains }\end{array}$ & $\begin{array}{l}\text { Germination } \\
\text { of pollen } \\
\text { grains }\end{array}$ & $\begin{array}{l}\text { Pollen } \\
\text { germination } \\
\text { percentage }\end{array}$ & $\begin{array}{l}\text { Pollen tube } \\
\text { length }(\mu \mathrm{m})\end{array}$ \\
\hline $5 \%$ & 165 & 64 & $38.7 \%$ & $373.2 \pm 64.5$ \\
\hline $10 \%$ & 229 & 103 & $44.97 \%$ & $428.8 \pm 51.5$ \\
\hline $20 \%$ & 115 & 42 & $36.52 \%$ & $282.6 \pm 47.4$ \\
\hline
\end{tabular}

Table 3: Pollen Viability

\begin{tabular}{|c|c|c|}
\hline $\begin{array}{c}\text { Total no of } \\
\text { pollen }\end{array}$ & $\begin{array}{c}\text { No. of viable pollen } \\
\text { present }\end{array}$ & \% of viability \\
\hline 143 & 69 & $48.25 \%$ \\
\hline
\end{tabular}




\section{International Journal of Science and Research (IJSR) \\ ISSN (Online): 2319-7064}

Index Copernicus Value (2013): 6.14 | Impact Factor (2014): 5.611

Table 4: Frequency of seed number per fruit level in Croton scabiosus

\begin{tabular}{|c|c|c|c|c|c|c|}
\hline $\begin{array}{c}\text { Number of fruits } \\
\text { observed }\end{array}$ & \multicolumn{6}{|c|}{ Frequency of seed number per fruit } \\
level
\end{tabular}

\section{Discussion}

The observations on phenology and floral biology of Croton scabiosus revealed that flowering occurs in two spans i.e., from January to June and September to October in the dry deciduous forests of Southern Eastern Ghats of Kadapa district. Similarly two flowering seasons are reported in other Euphorbiaceae species like Jatropha curcas (Sukarin et al. 1987) and Jatropha gossipifolia (Bebawi et al. 2005). Flower anthesis occurs throughout the day i.e., morning 0600 to 1800 hrs. But in Croton bonplandianum the flowers open in evening (17.30-19.00 hrs) but continued up to next day morning $(9.30 \mathrm{hrs})$ and sporadic flower opening occur throughout the day depend upon the climate condition (Biswas 2012). In the present study it was observed that the flowers are visited by only ants and thrips. They help in pollination by carrying a considerable amount of pollen through their body surface. As the flowers are unisexual both geitonogamy and xenogamy operate. The fruit set in high in natural condition (46\%) when compared to artificial pollination. Fruit set by geitonogamy $(23 \%)$ is high compared to xenogamy $(17.67 \%)$ indicating that plants are self compatible. Though average fruit set is observed poor, germination of seeds with $10 \%$ is recorded. This is due to seed infestation and predation. Many seedlings were found congregated near the mother plant indicating vegetative propagation. Nutrient poor habitat, frequent fires, rocky habitat and habitat degradation are the factors of threat to this species. The information on floral biology, pollination and breeding systems is a prerequisite for knowing the life history of Croton scabiosus which is an endemic tree and shows restricted distribution. It is monoecious tree and self compatable. Information on flowering period, floral anthesis, pollen dehiscence, pollen viability and floral characters will be helpful for further studies on breeding systems.

\section{Acknowledgements}

The authors are grateful to University Grants Commission New Delhi, India for the financial support to the project and Forest Department, Andhra Pradesh for giving permission to work in the forests of Kadapa

\section{References}

[1] Ahmedulla, M., Nayar, M.P. 1987 Endemic Plants of the Indian region. Vol.1. Peninsular India, Botanical Survey of India, Calcutta.

[2] Babu, P.S.P. 1997 Euphorbiaceae. In: Pullaiah T \& Moulali DA (eds.). Flora of Andhra Pradesh, India Vol.2. Scientific Publishers, Jodhpur, pp 836 - 890.

[3] Balakrishnan, N.P., Chakrabarty, T. 2007 The Family Euphorbiaceae in India. Bishen Singh Mahendra Pal Singh, Dehradun.
[4] Bebawi, F.F., Mayer, R.J., Campbel,1 S.D. 2005 Phenology of bellyache bush (Jatropha gossypifolia L.) in northern Queensland. Plant Protection Quarterly 20: $46-51$

[5] Biswas, K., Mindal, S., Mandal, S. 2012 Floral biology and pollen dispersal of Croton bonplandianum Baill. In: Maiti G \& Mukherjee S (eds.) Multidisciplinary approaches in Angiosperm Systematics pp. 756-761.

[6] Brewbaker, J.L. and Kwack ,B.H. 1963.The essential role of the calcium ion in the pollen germination and pollen tube growth. Amer. J. Bot. 50: $859-865$.

[7] Cruden, R.W. 1997 Pollen - ovule ratios: a conservative indicator of breeding system in flowering plants. Evolution. 31: $32-46$.

[8] Dafni, A. 1992 Pollination ecology: A practical approach. Oxford University Press, Oxford.

[9] Devi, S.N., Mani, J., VenkataRaju, R.R. 2011 In Vitro antimicrobial activity and phytochemical constituents of Croton scabiosus Bedd. Intern. J. Pharmaceut. Res. Dev. 3 (6): 149 - 154.

[10]Kearns, C.A., Inouye, D.W. 1993 Techniques for pollination biologist. University Press. Colorado. Niwot. Colorado.USA.

[11] McKone, M.I., Webb, C.J. 1988 A difference in pollen size between the male and hermaphrodite flowers of two species of Apiaceae. Aust. J.Bot. 36: 331-337.

[12]Neginhal, S.G. 2014 Forest trees of South India. Navabharath press, Bangalore.

[13] Salamma, S., Rao, B.R.P. 2014. Distribution and conservation status of Croton scabiosus Bedd. (Euphorbiaceae) an endemic tree species of southern Eastern Ghats of Andhra Pradesh. India. .J. Threatened $\begin{array}{llllll}\text { Taxa } & 6 & (\mathbf{1 0}) & 6363 & - & 6370\end{array}$ http.//dx.doi.org/10.11609/JoTT.04060. $6363-70$

[14] Shivanna, K.R., Rangaswamy, N.S. 1992 Pollen biology: A laboratory manual, Narosa publishing House, New Delhi.

[15] Sukarin, W., Yamada, Y., Sakaguchi, S.1987.Characteristics of physic nut, Jatropha curcas L. as a new biomass crop in the tropics. Japan Agricultural Research Quarterly 20: 302 - 303. 